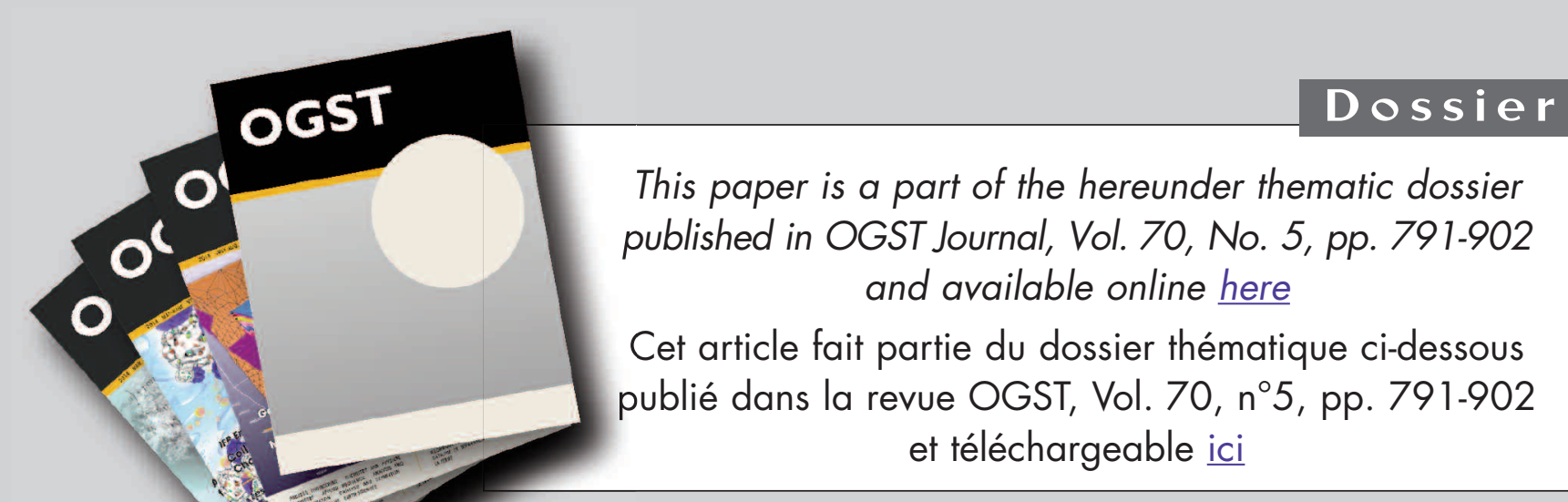

DOSSIER Edited by/Sous la direction de : D. Uzio

IFP Energies nouvelles International Conference / Les Rencontres Scientifiques d'IFP Energies nouvelles

$$
\begin{gathered}
\text { PHOTO4E - Photocatalysis for energy } \\
\text { PHOTO4E - Photocatalyse pour l'énergie }
\end{gathered}
$$

Oil \& Gas Science and Technology - Rev. IFP Energies nouvelles, Vol. 70 (2015), No. 5, pp. 791-902

Copyright (C) 2015, IFP Energies nouvelles

$791>$ Editorial

M. Fontecave, A. Fécant and D. Uzio

$799>$ Solar Production of Fuels from Water and $\mathrm{CO}_{2}$ : Perspectives and Opportunities for a Sustainable Use of Renewable Energy

Production solaire de carburants à partir de l'eau et de $\mathrm{CO}_{2}$ : perspectives et opportunités pour une utilisation durable de l'énergie renouvelable

R. Passalacqua, G. Centi and S. Perathoner

817 > Effect of Post-Synthesis Treatments on the Properties of ZnS Nanoparticles: An Experimental and Computational Study

Effet des traitements après-synthèse sur les propriétés de nanoparticules de ZnS : une étude expérimentale et computationnelle

E. Balantseva, B. Camino, A.M. Ferrari and G. Berlier

831 > Comparative Study on The Photocatalytic Hydrogen Production from Methanol over $\mathrm{Cu}_{-}, \mathrm{Pd}$-, Co- and Au-Loaded TiO

Étude comparative de production d'hydrogène par photocatalyse à partir de méthanol et à l'aide de différentes phases actives ( $\mathrm{Cu}, \mathrm{Pd}, \mathrm{Co}$ et Au) supportées sur TiO

P.P.C. Udani and M. Rønning

841 > Photocatalytic Conversion of Carbon Dioxide Using Zn-Cu-Ga Layered Double Hydroxides Assembled with Cu Phthalocyanine: Cu in Contact with Gaseous Reactant is Needed for Methanol Generation

Conversion photocatalytique du dioxyde de carbone par des hydroxydes doubles lamellaires de Zn-Cu-Ga promus par la phtalocyanine de Cu : nécessité du contact entre le Cu et le réactif gazeux pour la synthèse du méthanol

S. Kawamura, N. Ahmed, G. Carja and Y. Izumi
$853>$ Recyclable PhotoFuel Cell for Use of Acidic Water as a Medium Cellule photocombustible recyclable pour I'utilisation d'eau acide en tant que milieu

Y. Ogura, M. Yoshiba, and Y. Izumi

$863>$ Solar Hydrogen Reaching Maturity L'hydrogène solaire arrive à maturité

J. Rongé, T. Bosserez, L. Huguenin, M. Dumortier, S. Haussener and J.A. Martens

877 > Design of Compact Photoelectrochemical Cells for Water Splititing Conception de cellules photoélectrochimiques compactes pour la décomposition de l'eau

T. Bosserez, J. Rongé, J. van Humbeeck, S. Haussener and J. Martens

891 > Simultaneous Production of $\mathrm{CH}_{4}$ and $\mathrm{H}_{2}$ from Photocatalytic Reforming of Glucose Aqueous Solution on Sulfated Pd-TiO, Catalysts Production simultanée de $\mathrm{CH}_{4}$ et $\mathrm{H}_{2}$ par réformage photocatalytique d'une solution aqueuse de glucose sur un catalyseur Pd-TiO, sulfaté V. Vaiano, G. lervolino, G. Sarno, D. Sannino, L. Rizzo, J.J. Murcia Mesa, M.C. Hidalgo and J.A. Navío 


\title{
Solar Hydrogen Reaching Maturity
}

\author{
Jan Rongé $^{1 *}$, Tom Bosserez ${ }^{1}$, Louis Huguenin ${ }^{1,2}$, Mikaël Dumortier ${ }^{2}$, \\ Sophia Haussener ${ }^{2}$ and Johan A. Martens ${ }^{1}$ \\ ${ }^{1}$ Centre for Surface Chemistry and Catalysis, KU Leuven, Kasteelpark Arenberg 23/2461, 3001 Leuven - Belgium \\ ${ }^{2}$ Laboratory of Renewable Energy Science and Engineering, EPFL, Station 9, 1015 Lausanne - Switzerland \\ e-mail: jan.ronge@biw.kuleuven.be \\ * Corresponding author
}

\begin{abstract}
Increasingly vast research efforts are devoted to the development of materials and processes for solar hydrogen production by light-driven dissociation of water into oxygen and hydrogen. Storage of solar energy in chemical bonds resolves the issues associated with the intermittent nature of sunlight, by decoupling energy generation and consumption. This paper investigates recent advances and prospects in solar hydrogen processes that are reaching market readiness. Future energy scenarios involving solar hydrogen are proposed and a case is made for systems producing hydrogen from water vapor present in air, supported by advanced modeling.
\end{abstract}

Résumé - L'hydrogène solaire arrive à maturité — Des efforts toujours plus importants sont consacrés au développement de matériaux et de processus permettant la production d'hydrogène par dissociation d'eau utilisant l'énergie solaire. Le stockage d'énergie solaire par voie chimique résout les problèmes associés à la nature intermittente de cette ressource. La génération et la consommation d'énergie sont ainsi découplées. Cet article examine les récents progrès obtenus sur les processus permettant la production d'hydrogène solaire prêts pour commercialisation. Il propose également des scénarios énergétiques innovants utilisant l'hydrogène solaire. Enfin, un dispositif permettant la production d'hydrogène utilisant la vapeur d'eau présente dans l'air ambiant est étudié avec l'appui de la modélisation numérique.

\section{INTRODUCTION}

Our emancipation from fossil fuels in the long term will have to be supported by solar energy capture. The average global energy consumption rate today is $15 \mathrm{TW}$ and estimated to increase to $30 \mathrm{TW}$ by 2050 [1]. Renewable sources such as wind and biomass could each deliver less than $10 \mathrm{TW}$ when deployed all over the world [1]. The potential of solar energy however seems practically unlimited. Fossil fuels, plants and wind are all derived from solar energy. To capture $30 \mathrm{TW}$ of solar energy using $10 \%$ efficient PhotoVoltaic (PV) panels, $0.24 \%$ of the Earth's surface is needed [1]. Although this may seem a small number in terms of land usage, there are serious technical challenges. To put this number into perspective, we note that currently $c a$. $0.4 \%$ of the Earth's surface is covered by roads in rural areas, and $c a .2 .8 \%$ of the Earth's surface is urbanized [2]. The main hurdle impeding large-scale implementation of solar energy is its unreliability. PV produce electricity, which is difficult and costly to store. Due to the intermittent nature of solar energy, it is currently difficult to integrate large capacities of PV into an energy supply strategy. For example, Germany drastically reduced its dependence on nuclear energy and is investing strongly in renewables, but now relies on coal and gas fired power plants to balance its energy supply and demand [3]. Additionally, models predict 
an overload of electricity grids when operated at high renewables capacity [3], invigorating the need to buffer energy generation using energy storage technologies.

Hydroelectric and compressed air storage are robust strategies to store solar energy. They have a relatively low cost, but can only be applied on a large scale and capacity is limited in most regions [4, 5]. Batteries are an option for storing electrical energy, but their high economic and environmental costs have a negative effect on the overall impact of renewable energy generation and storage strategies [6]. Over its entire lifetime, a typical lead-acid battery can only store and discharge five times the amount of energy needed to produce the battery. This number only increases to 32 for modern lithium ion batteries [6]. The key to large-scale solar energy capture is storage in the chemical bonds of a fuel molecule with high energy density. Plants fix solar energy in carbohydrates starting from water and $\mathrm{CO}_{2}$. For artificial systems, splitting water into oxygen and $\mathrm{H}_{2}$ seems a more realistic approach. $\mathrm{H}_{2}$ can be converted into electricity using Fuel Cells (FC), with only water as a side product, or burnt in conventional internal combustion engines.

$\mathrm{H}_{2}$ is central to the development of a hydrogen economy, which is already starting today. About $100 \mathrm{H}_{2}$ fueling stations exist in the United States, most of which are in private ownership by companies [7-9]. Los Angeles hosts 8 public fueling stations, and 100 more are planned in California by 2024. In Europe, Germany is at the forefront of public $\mathrm{H}_{2}$ fueling stations. The current number of $c a$. 20 is to be augmented to 400 by 2023 . A solar-driven station was planted at Freiburg, which produces its own $\mathrm{H}_{2}$ using solar energy captured by PV panels on the roof. Almost 20 such stations exist in Germany and the US. A solar $\mathrm{H}_{2}$ fueling station for residential use was presented by Honda [10], and Nanoptek developed a water splitting device that combines an integrated photocatalyst with external PV panels [11]. One of the main energy applications of $\mathrm{H}_{2}$ today remains its use in forklifts in distribution centers. Over 6200 such forklifts are in operation in the US, used by companies as Walmart, Sysco, Central Grocers and BMW. Colruyt, a Belgian retailer, together with WaterstofNet and Hydrogenics installed a $\mathrm{H}_{2}$ fueling station that is powered by their own excess wind and solar energy [12]. Another success story of $\mathrm{H}_{2}$ was found in public transportation, with dozens of $\mathrm{H}_{2}$ based buses involved in pilot projects in cities such as London, Beijing, Berlin and Perth [13-15]. Despite the deployment of $\mathrm{H}_{2}$ infrastructure on several locations, solar production of $\mathrm{H}_{2}$ remains a challenge. The main factor to deal with is cost, illustrated by the change of strategy of Sun Catalytix, a spin-off company of the Massachusetts Institute of Technology. It aimed to commercialize its 'artificial leaf', a solar device that directly produces $\mathrm{H}_{2}$ from water. Despite its simple design and use of earth-abundant materials, it could hardly compete with conventional PV [16]. Widespread solar $\mathrm{H}_{2}$ is within reach, and the final steps toward practical application are outlined in this paper. We will discuss two approaches:

- a conventional water electrolyzer driven by an external PV panel (PV/electrolysis);

- a PhotoElectroChemical (PEC) cell that integrates photoactive and electrochemical components in a single device.

\section{SOLAR HYDROGEN PROCESSES}

\subsection{Photovoltaic-Coupled Electrolyzer (PV/Electrolysis)}

The PV/electrolysis approach relies on the achievements made in the PV sector over the last decades. While PV efficiencies have increased to $15-20 \%$ for commercial systems, module cost continues to decrease. Many buildings are already equipped with PV panels and could be retrofitted with an electrolyzer to produce $\mathrm{H}_{2}$ when surplus electricity is available. This $\mathrm{H}_{2}$ would then be stored locally and reconverted to electricity in a FC when supply cannot meet demand, e.g. at night (Fig. 1). Even when PV is not available on-site, grid electricity could be used provided the electricity is supplied by renewable technologies. The effect of storing surplus energy for later use is demonstrated in Figure 2. The capacity factor is defined as the yearly electricity output relative to the installed capacity. Currently installed PV operate on average at about $12 \%$ of their capacity [17]. This means PV installations have to be over-dimensioned $\sim 8$ times to supply enough energy on average. Depending on the overlap between energy generation and demand, a large part of the generated electricity will not be consumed immediately, but shall have to be stored as $\mathrm{H}_{2}$. Assuming only $20 \%$ of the electricity is used directly, solar energy capture increases from $0.22 \mathrm{kWh} \mathrm{m}^{-2}$ day $^{-1}$ for $\mathrm{PV}$ to $0.62 \mathrm{kWh} \mathrm{m}^{-2} \mathrm{day}^{-1}$ for a PV/electrolyzer setup. Note that the energy contribution of $\mathrm{H}_{2}$-derived electricity is lower than the contribution of direct solar-to-electricity conversion, since the overall efficiency is lower when $\mathrm{H}_{2}$ has to be generated and stored. This is a drawback of PEC cells, which always produce $\mathrm{H}_{2}$ and cannot be used for direct electricity generation.

Since electrolyzers operate at a voltage around 1.9 V [19], a DC-DC converter is needed to match PV output voltage and the voltage of the electrolyzer at its design point. The best choice for the electrolyzer is a Polymer Electrolyte Membrane (PEM) electrolyzer, since this type can more easily handle fluctuating input currents [20]. It can be scaled much smaller than the PV modules, since sunshine is diffuse (100 $\mathrm{mW} \mathrm{cm}{ }^{-2}$, corresponding to maximal photocurrents around $20-30 \mathrm{~mA} \mathrm{~cm}^{-2}$ ) and electrolyzers economically 


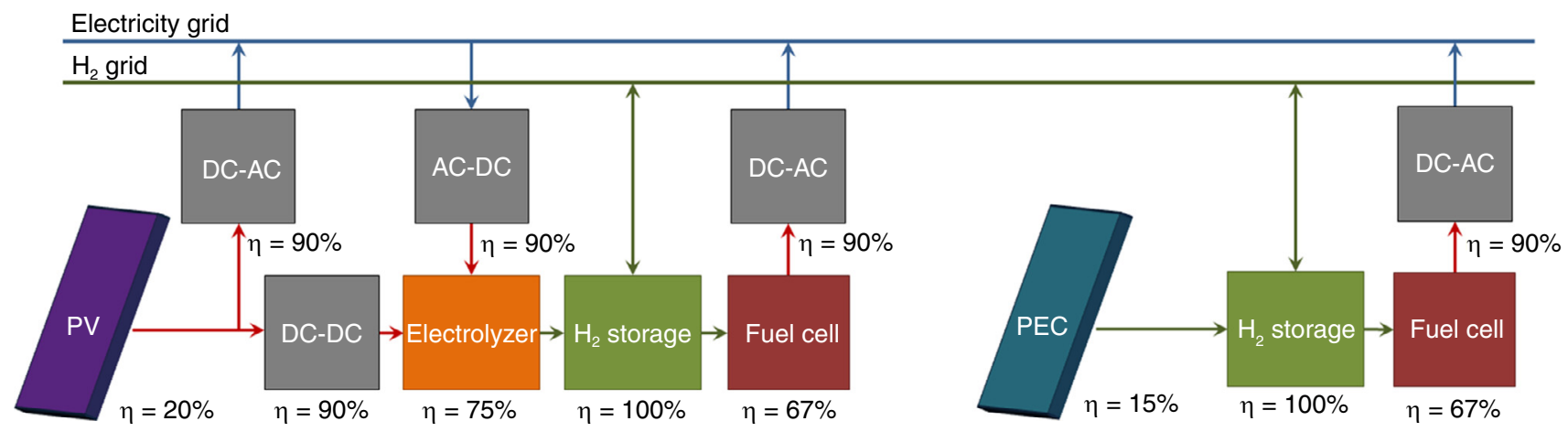

Figure 1

Configuration of components for PV/electrolyzer (left) and PEC cell (right) setups. Efficiency of each process is indicated. Storage and distribution energy losses are not taken into account $(\eta=100 \%)$.

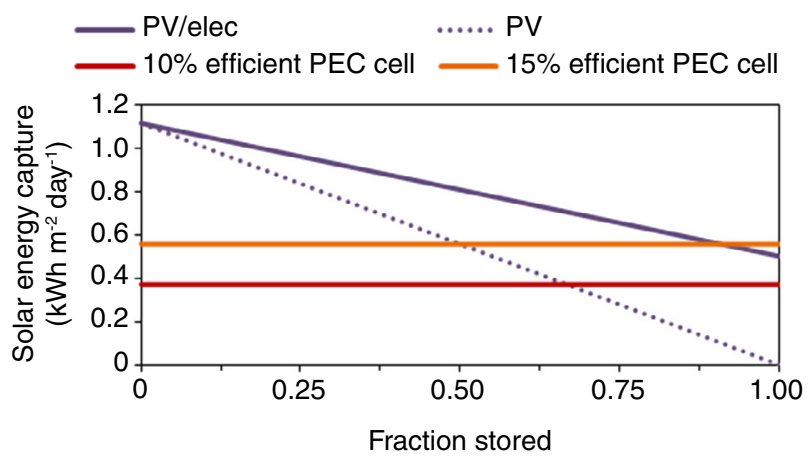

Figure 2

Solar energy capture of PV, PV/electrolysis and PEC systems depending on the fraction of energy stored for later use. Efficiencies used for calculation are indicated in Figure 1. Average yearly solar irradiation is taken as $6.19 \mathrm{kWh} \mathrm{m}^{-2}$ day $^{-1}$ [18].

operate at high current densities of $>1 \mathrm{~A} \mathrm{~cm}^{-2}$ [21]. Moreover, because PV efficiency decreases with temperature and electrolyzer efficiency is highest at elevated temperatures, both can be put in different locations to address these requirements [19, 22]. On the other hand, Rau et al. [20] reason that a PEM electrolyzer directly attached to the back of a PV module would cool down the module, so enhancing its efficiency. Building upon earlier work [23], they engineered integrated PV/electrolyzer modules without the need for a DC-DC converter. In this case, the characteristics of each PV module have to be closely matched to those of the electrolyzer. In particular, the PV should provide sufficient potential to achieve water electrolysis and optimal current output for maximal use of the expensive electrolyzer [24]. In this work, two PV junctions were stacked to increase output potential and efficiency. The electrolyzer surface area was then adjusted as a function of the current output of the solar cell, to achieve operation near the maximal power point [20].

Jacobsson et al. [25] went one step further and directly attached electrodes to the back of a solar cell, which was separated from the electrolyzer environment by a polymer film, glass and epoxy resin. This type of set-up is at the boundary of PV/electrolysis and 'true' integrated devices (Fig. 3). The strict separation of devices into two categories is counterproductive however, as one field can learn from the other [26]. One could distinguish between twocomponent systems containing PV modules externally wired to electrolyzers, and more integrated singlecomponent systems. The former benefit from the possibility of direct utilization of electricity, whereas the latter always produce $\mathrm{H}_{2}$, but are expected to result in lower capital costs (vide infra).

\subsection{Integrated Photoelectrochemical Cells (PEC Cells)}

PEC cells combine all functions of a solar $\mathrm{H}_{2}$ system in a single unit. While technically challenging, the reward is a practical device with a minimal amount of peripherals and material usage. An issue faced by PV manufacturers is how to collect electrons through front contacts, without blocking incoming light. For the electrolyzer, the charge carrying supports contribute to the overall cost. In addition, charge collection and transport cause ohmic losses. These intermediary steps are avoided in a PEC cell. Since the semiconductor can be put in direct contact with the electrolyte, charge carriers are immediately consumed in oxidation and reduction reactions at the surface, and low cost materials with short charge carrier diffusion distances may be used [27]. Moreover, a semiconductor-liquid junction formed at the interface aids charge separation 

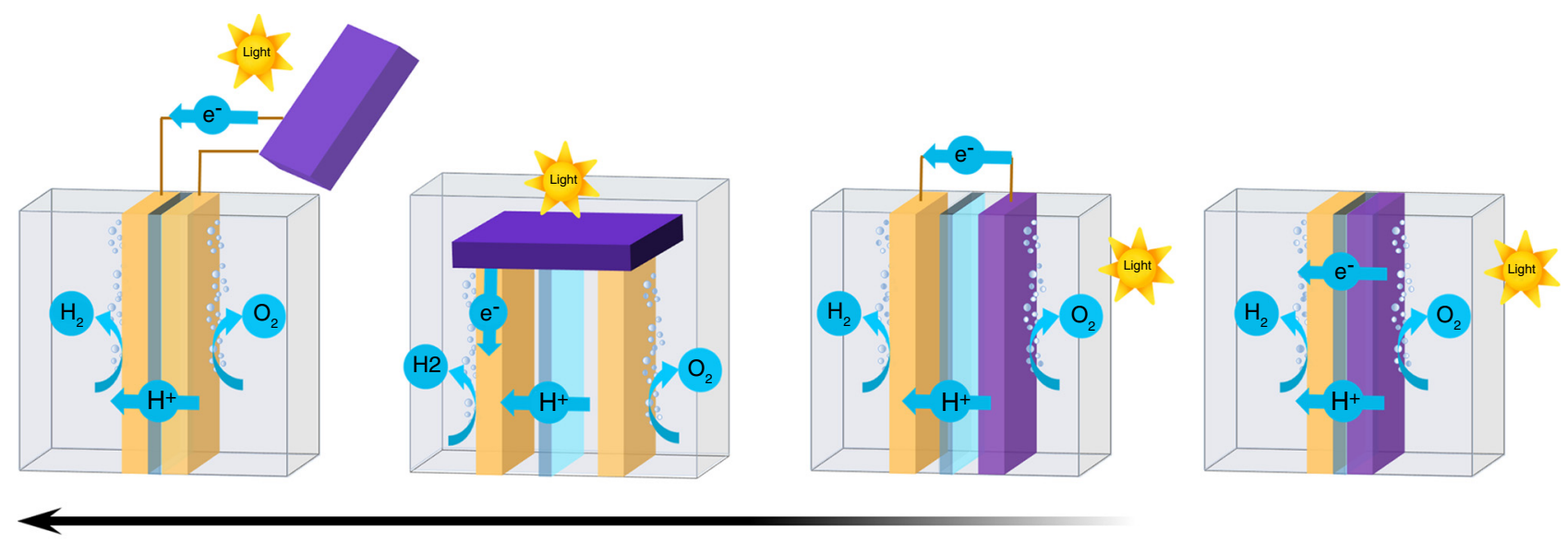

PV/electrolysis

PEC

Figure 3

Overview of solar $\mathrm{H}_{2}$ cells. From left to right: PV/electrolysis, electrodes attached to the back of a solar cell, wired PEC cell with photoelectrode, wireless monolithic PEC cell.

and could replace the solid state $p$ - $n$ junction required in PV [28]. Due to reduced complexity, material use and energy losses, the use of PEC cells could result in lower overall cost. However, there is an important caveat: these benefits can be achieved only if several important difficulties are addressed. Existing PV cells were not conceived as electrochemical reactors, so a drastic change in materials and design is needed for PEC cells. Corrosion issues, ion transport and gas evolution should all be taken into account. Moreover, since the PEC cell is the same size as a PV device and thus much larger than the corresponding electrolyzer, the electrolytic components of a PEC cell (e.g. catalysts) should be much cheaper. These requirements are not all met by current PEC systems.

Many systems consist simply of a semiconductor material on a back contact, wired to a counter electrode and submerged in solution. Direct attachment of the counter electrode to the back of the semiconductor results in a wireless current, which reduces electric losses and simplifies the design (Fig. 3). Besides electrical (and optical) requirements, PEC cells should also allow for ionic transport and achieve product separation. Co-evolution of $\mathrm{H}_{2}$ and $\mathrm{O}_{2}$ should be avoided at all costs for reasons of safety, system complexity (no additional product separation) and product yield (no back reaction). In addition, post-reaction product processing would lead to additional energy losses [29]. Similar to FC, separation of reduction and oxidation sites by an ion exchange membrane can prevent mixing of product gases but still allows ionic transport.
Porous, monolithic semiconductor-catalyst assemblies embedded in ion exchange membrane fulfill at the same time the optical, electrical and chemical requirements [27]. Such systems are denoted as solar membranes, analogous to the thylakoid membrane found in chloroplasts.

PV/electrolysis set-ups have demonstrated SolarTo-Hydrogen (STH) efficiencies from $10 \%$ up to $18 \%$ $[20,23-25,27]$. Accounting for a DC-DC converter efficiency of $90 \%$ and $75 \%$ efficient electrolyzer, in theory STH efficiencies of up to $18.6 \%$ or $30 \%$ are possible using state-of-the art silicon or III-V solar cells, respectively [30]. Modeling indicated that PEC cells could outperform $\mathrm{PV} /$ electrolysis set-ups on annual basis, thanks to better performance at higher temperatures [22]. However, the best PEC cells at the moment achieve efficiencies of only $4-12 \%$, mostly due to corrosion issues, charge carrier recombination or suboptimal ion transport [27]. Based on existing materials, Seitz et al. [31] calculated maximal STH efficiencies of $11.2 \%$ for single junction PEC cells and $22.8 \%$ for stacked dual junction PEC cells. Rocheleau and Miller [32] estimated STH efficiencies of $16.1 \%$ and $26 \%$, respectively. In a theoretical prospective study, $\mathrm{Hu}$ et al. [33] determined $31.1 \%$ STH efficiency to be the ultimate limit for dual junction PEC cells. To achieve these numbers, energy losses in photoelectrochemical cells will have to be minimized, and subsequently semiconducting materials have to be found that match the electrical energy needs of the system and maximally capture solar energy. 


\section{REQUIREMENTS FOR PRACTICAL SOLAR HYDROGEN SYSTEMS}

\subsection{Cost}

Most of the $\mathrm{H}_{2}$ today is produced via steam methane reforming, at prices down to $1 \$ \mathrm{~kg}^{-1} \mathrm{H}_{2}$ [18]. Competing technologies are centralized biomass gasification and wind electrolysis, with prices of $1.6 \$ \mathrm{~kg}^{-1}$ and $4.5 \$ \mathrm{~kg}^{-1}$, respectively (distribution costs not included) [18]. Solar $\mathrm{H}_{2}$ is not yet cost effective today [34]. In its Hyways roadmap, the European Commission targets a distributed solar $\mathrm{H}_{2}$ price of $4 € \mathrm{~kg}^{-1}$ by 2020 and $3 € \mathrm{~kg}^{-1}$ by 2030 [35]. The US Department of Energy aims for $5 \$ \mathrm{~kg}^{-1}$ by 2017 and $4 \$ \mathrm{~kg}^{-1}$ by 2020 (distribution costs not included). A distributed $\mathrm{H}_{2}$ price of 2-4 $\$ \mathrm{~kg}^{-1}$ is assumed to be costcompetitive with $\mathrm{H}_{2}$ derived from fossil fuels [36]. Parkinson and Turner argue that this metric is unrealistic as it directly compares the cost of renewable and methanederived $\mathrm{H}_{2}$. Instead, they propose to compare costs based on affordability, factoring in also the cost of greenhouse gases emitted by fossil fuels. Taking gasoline as a benchmark, they propose a target $\mathrm{H}_{2}$ cost of $6 \$ \mathrm{~kg}^{-1}$ [37].

A technoeconomic analysis of centralized facilities based on PEC cells predicted that prices between $2.9-18.8 \$ \mathrm{~kg}^{-1}$ could be achieved, including pressurization of the $\mathrm{H}_{2}$ [18]. The analysis also considered costs related to land usage, personnel, maintenance and process control. The large variation in cost estimation is due to a number of uncertainties:

- capital cost,

- efficiency,

- lifetime.

The influence of these parameters on a PEC cell is given in Figure 4. Several scenarios fit the targeted $\mathrm{H}_{2}$ cost. A cheap and efficient device is allowed to have a shorter lifetime, although there are practical limitations and costs increase exponentially at lifetimes of $<5$ years. Low-cost PEC cells with efficiencies around 5\% have been demonstrated [27], but in the long term an efficiency of $15 \%$ would substantially facilitate reaching the cost objectives [18]. The cost could also be reduced under the influence of a carbon tax or government subsidies [38]. On the other hand, PV panels and electrolyzers have been investigated for decades and only incremental improvements to their efficiency are to be expected in the future. Capital cost and electrolyzer lifetime are the most important parameters to bring down the cost of $\mathrm{H}_{2}$ from PV/electrolysis [39]. Whereas the cost of PV panels has been steadily decreasing for decades, it may prove difficult to sufficiently lower the cost of existing electrolyzers employing expensive polymer membranes and noble metal catalysts [26, 40]. Although a comparative assessment of both solar $\mathrm{H}_{2}$ approaches was not yet

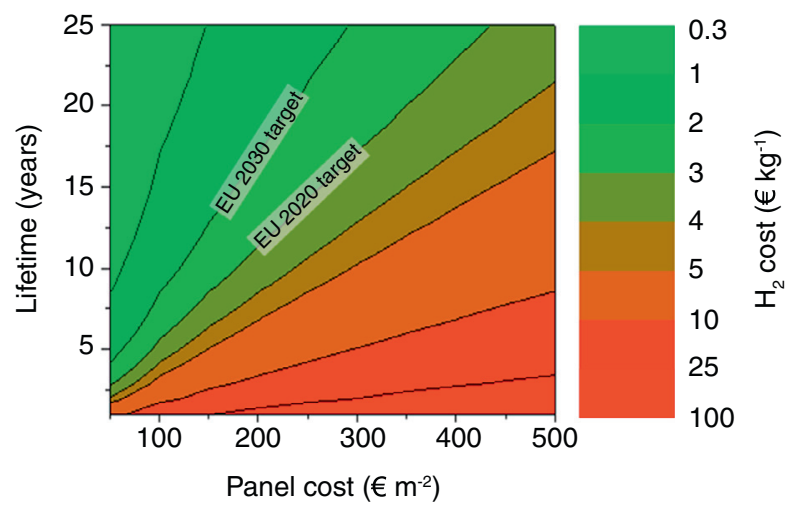

Figure 4

Cost of $\mathrm{H}_{2}$ produced by a PEC device with $10 \%$ efficiency as a function of panel lifetime and cost. The calculations only include capital costs, maintenance and process control costs. EU targets (including distribution costs) for 2020 and 2030 are indicated.

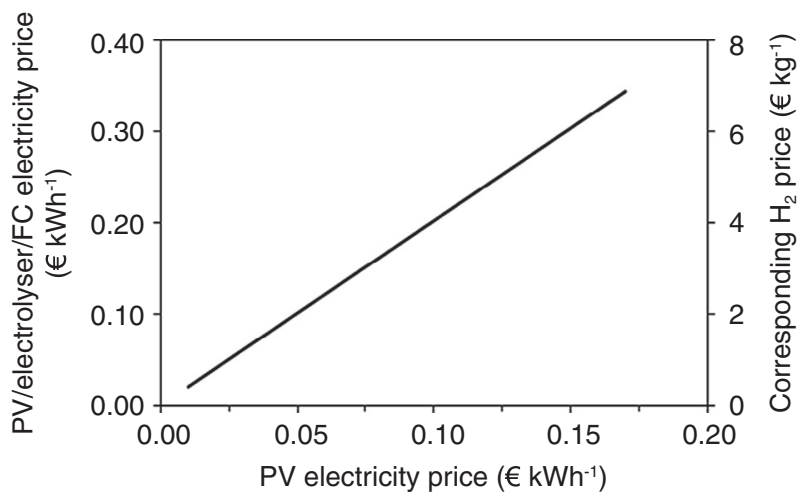

Figure 5

Cost of electricity from PV/electrolysis/FC and corresponding $\mathrm{H}_{2}$ price, depending on PV electricity price. Electrolyzer capital cost, storage and distribution costs are not included.

performed, PEC cells bear the promise to reduce capital costs since all components are contained in a single system, and possibly some components can assume multiple functions (e.g. PV and membrane functions can be integrated in a single material [41]). Figure 5 shows the electricity price from a PV/electrolyzer/FC system as a function of PV electricity price, without taking into account electrolyzer capital costs or storage and distribution costs. For a corresponding $\mathrm{H}_{2}$ price of $2-4 € \mathrm{~kg}^{-1}$, PV electricity should be delivered at $0.05-0.1 € \mathrm{kWh}^{-1}$. In reality lower prices are desired, as additional capital and distribution costs have to be covered. $\mathrm{H}_{2}$ cost has been assessed for centralized $\mathrm{H}_{2}$ production via integrated PV/electrolysis plants. Without including storage 
and distribution costs, with $10-14 \%$ efficient $\mathrm{PV}$ and a 20-30 year lifetime $\mathrm{H}_{2}$ cost was estimated at 4.70$5.86 \$ \mathrm{~kg}^{-1}$ [42]. If PV plants would reach lifetimes of 60 years and $16 \%$ efficiency, $\mathrm{H}_{2}$ prices could go down to $1.90 \$ \mathrm{~kg}^{-1}$.

\subsection{Lifetime}

The influence of lifetime on cost is apparent from Figure 4. PEC cell lifetime is determined mainly by corrosion of semiconductors, catalyst poisoning and membrane contamination by salts. Many of the state-of-the-art PEC cells operate in highly acidic or basic electrolytes which more easily cause corrosion of semiconductors and catalysts. Working in near-neutral electrolytes would relax the stability requirements but problems arise due to the depletion of supporting electrolyte. A PEC device operated in near neutral medium has been proposed with recirculation of the electrolyte to maintain stability over longer periods [43]. A lot of work has been done recently on protective ultrathin coatings to prevent corrosion [44]. Many PEC cells are found to be stable at least for several hours. The US Department of Energy put forward a target of 5000 hours stable operation by 2018 [45]. In PV/electrolysis cells, the PV component is not exposed to a harsh environment and will probably last as long as conventional PV. In this case, the electrolyzer may be replaced when necessary while the PV remains.

Performance stability over time is also important. If the efficiency degrades, this again badly affects $\mathrm{H}_{2}$ cost. On the other hand, the amount of maintenance required has an influence on cost, capacity factor (downtime during maintenance) and practical applicability. High-maintenance systems are less appropriate for remote or residential applications.

\subsection{Scalability}

When increasing the scale of solar $\mathrm{H}_{2}$ systems from lab to industrial scale the following issues should be dealt with:

- engineering considerations,

- materials and fabrication procedures,

- safety and environmental issues.

\subsubsection{Engineering Considerations}

Reactor engineering is an aspect which is seldom discussed in literature, but which may have a large influence on the choice of candidate materials. Reactors should be as simple as possible, low cost and low maintenance. PEC cells have the advantage of device simplicity, as no separate electrolyzer is required. On the other hand, the integration of multiple functions in a single reactor may complicate the interior architecture of the device [27].
An increase of a panel's surface area should result in a proportional increase of the $\mathrm{H}_{2}$ output. Current lab-scale systems often do not take into account mass transport energy losses when device dimensions are increased. Haussener et al. [46] showed by numerical modeling that for devices based on dense PV, increasing surface area may result in tremendous overpotential losses. This was ascribed to ionic transport difficulties. On the other hand, electronic transport can be limiting when electrodes are based on transparent conducting oxides such as indium- or fluorine-doped tin oxide. Such back contacts have low conductivity and fail even at dimensions of a few $\mathrm{cm}^{2}$ [47].

\subsubsection{Fabrication and Materials}

If solar $\mathrm{H}_{2}$ generation is to be deployed on a global scale, the use of abundant materials is imperative [48]. In this respect widespread use of electrolyzers containing high loadings of scarce Pt seems unlikely. Electrolyzers and PEC devices can circumvent this contradiction either by drastically reducing $\mathrm{Pt}$ loading or by using earth-abundant elements $(\mathrm{Co}, \mathrm{Ni}$, $\mathrm{Fe}$ ) [49]. In either case, the device will have to be run at lower current density. PEC cells have low current density limited by solar illumination, and are perfectly suited to incorporate catalysts made of abundant elements. For PV/electrolyzer setups, the use of less noble metals will require an increase in electrolyzer surface area. Many PEC cells contain metal oxides based on earth-abundant elements $\left(\mathrm{BiVO}_{4}, \mathrm{WO}_{3}, \mathrm{Fe}_{2} \mathrm{O}_{3}, \mathrm{Cu}_{2} \mathrm{O}\right.$ ), but the most active examples also contain PV junctions based on $\mathrm{Si}$ [27]. Even though $\mathrm{Si}$ is the second most abundant element in the Earth's crust, the requirement of very high purity Si for PV devices makes their production process costly. Thin-film technology (amorphous silicon) is gaining a lot of interest as it requires less material, although efficiency generally is also lower. Besides the choice of materials, also the fabrication method should be suitable for scale-up. Often plasma-assisted vapor deposition methods are used which require vacuum pumping, but milder wet methods such as electrochemical deposition or even inkjet printing exist as well [27, 50, 51].

\subsubsection{Safety and Environmental Issues}

Solar $\mathrm{H}_{2}$ installations only make sense if they generate more renewable energy than it costs to fabricate them. This has been investigated by Life Cycle Assessment (LCA). LCA for large scale industrial PV/electrolysis has been carried out by Mason and Zweibel, partly based on data from existing PV plants [42]. They considered PV efficiencies of $10-14 \%$ and a lifetime of $20-60$ years. They show that $50 \%$ of the primary energy requirement is for the PV power plant, $9 \%$ is used in the electrolysis plant and the remaining energy is used for compressing and transporting the hydrogen fuel 


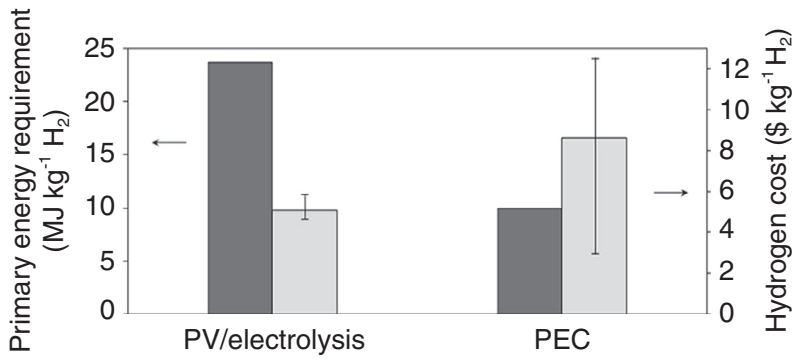

Figure 6

Comparison of primary energy (dark grey) and hydrogen cost (light gray) for large scale PV/electrolysis and integrated PEC plants $[18,42,50]$.

to fuel stations. For PEC cells, a LCA has been performed by Zhai et al. [50]. This study has a much wider range of uncertainty as the technology of PEC devices is not yet ready for practical applications. Three cases were considered with different types of materials, PEC efficiencies of $3-10 \%$ and lifetimes of 5-30 years. They showed that photoelectrode fabrication is the most energy-consuming process. The results indicate that the energy needed to build PEC plants could be significantly lower compared to PV/ electrolysis (Fig. 6). A 10\% efficient PEC device with a lifetime of 30 years requires as little as $10 \mathrm{MJ} \mathrm{kg}^{-1} \mathrm{H}_{2}$ primary energy, whereas a PV/electrolysis plant with $12 \%$ efficient $\mathrm{PV}$ and 30 years lifetime is estimated to require $23.7 \mathrm{MJ} \mathrm{kg}^{-1} \mathrm{H}_{2}$. Energy cost of $\mathrm{H}_{2}$ pressurization and distribution is not included in these numbers, but should be comparable for both approaches. This analysis shows that even though PEC devices capture less solar energy per $\mathrm{m}^{2}$ (Fig. 2), primary energy requirement is lower due to a lower capital energy cost.

\section{ENERGY SCENARIOS}

\subsection{Centralized Solar Hydrogen Plants}

Our current energy production relies mainly on highly energy-dense fuels (fossil, nuclear), which are consumed in large-scale centralized power plants. Electricity is distributed to the consumers through the electricity grid. In a hydrogen economy, large-scale solar farms can be envisioned which follow the same logic and make use of the existing grid [5]. One of the most famous large solar projects is the Desertec Initiative. The consortium proposed a network of concentrated solar and other renewable power plants in Northern Africa and around the Mediterranean region [52]. The generated electricity is supplied to countries in
Europe, the Middle East and Northern Africa through a 'supergrid' of long distance high voltage direct current power lines, with an energy loss of 3\% per $1000 \mathrm{~km} \mathrm{[5].}$ For centralized $\mathrm{H}_{2}$ production facilities, $\mathrm{H}_{2}$ could be transported through pipelines and either be used as a fuel by end users or converted into electricity using FC. For low pressure transport, $\mathrm{H}_{2}$ could be mixed at low concentrations with natural gas and transported through the existing distribution grid [53]. For high pressure long distance transport, dedicated pipeline networks are more appropriate especially in the long run. In 2007, some $1600 \mathrm{~km}$ of $\mathrm{H}_{2}$ pipelines were already installed in Europe [54]. The $\mathrm{H}_{2}$ grid is currently used for transport of fossil fuel derived $\mathrm{H}_{2}$ to industrial sites.

Alternatively, $\mathrm{H}_{2}$ can be converted to hydrocarbon fuels using $\mathrm{CO}_{2}$ [55]. By coupling $\mathrm{H}_{2}$ production with atmospheric carbon capture and conversion, the economic value of atmospheric $\mathrm{CO}_{2}$ is boosted, so providing an incentive for this activity [56]. Through the reversed water gas shift reaction, syngas is produced (Eq. 1). Syngas can be further processed to yield methanol (Eq. 2) or a hydrocarbon mixture through the Fischer-Tropsch process (Eq. 3) [34, 55]. Another approach for storing excess energy in hydrocarbons is the Sabatier reaction, also known as methanation or power-to-gas conversion (Eq. 4). This process is being commercialized by companies such as Hydrogenics, Sunfire and ETOGAS [57-59]. Methane can easily be transported through existing pipeline networks and can be readily used in current infrastructure.

$$
\begin{gathered}
\mathrm{H}_{2}+\mathrm{CO}_{2} \rightarrow \mathrm{H}_{2} \mathrm{O}+\mathrm{CO} \\
\mathrm{CO}+2 \mathrm{H}_{2} \rightarrow \mathrm{CH}_{3} \mathrm{OH}
\end{gathered}
$$

$$
(2 n+1) \mathrm{H}_{2}+n \mathrm{CO} \rightarrow \mathrm{C}_{n} \mathrm{H}_{(2 n+2)}+n \mathrm{H}_{2} \mathrm{O}
$$

$$
\mathrm{CO}_{2}+4 \mathrm{H}_{2} \rightarrow \mathrm{CH}_{4}+2 \mathrm{H}_{2} \mathrm{O}
$$

Centralized facilities hold the promise of lower cost through economies of scale, the possibility of large scale post-processing and choice of an optimal location for solar energy capture. On the other hand, the need for long distance transport of energy carriers increases complexity and energy losses. Large areas of land are needed to host the power plants and locally large amounts of water are consumed as a feedstock and for cooling [42]. Moreover, complex large scale facilities increase costs for personnel, control systems and other infrastructure [18]. Semi-centralized facilities could provide a solution to these drawbacks. Office buildings and other infrastructure at the outskirts of metropolitan 
areas can host large surface areas of solar panels on the roof. $\mathrm{H}_{2}$ or other fuel can be transported at low pressures to end users over short distances. In contrast with dedicated $\mathrm{H}_{2}$ plants, this solution does not require additional personnel or land area and could significantly bring down capital costs. In this case, it is important to achieve autonomously operating cells and infrastructure that require little maintenance.

\subsection{Decentralized Residential Production}

One of the main benefits of sunlight is its omnipresence: solar energy can be harvested from almost any location on earth. It makes sense to use this advantage for the widespread deployment of solar energy devices in a distributed fashion. If we cover $\sim 8.6 \%$ of all urbanized area with solar panels, we can power the world $[1,2]$. Decentralized $\mathrm{H}_{2}$ production takes advantage of the enormous unused surface area of roofs by transforming each house into a power plant. It relaxes stresses on the distribution grid and increases energy security. It is more resilient than systems based on centralized power plants, and less susceptible to political instabilities or terrorist attacks [60, 61]. The solar panels are installed, paid for and managed by the inhabitants of the house. By giving people personal control over their energy production, a higher level of energy awareness is created, which could even result in reduced energy consumption [62]. Autonomous decentralized $\mathrm{H}_{2}$ systems can provide energy to remote areas and if made affordable, could be an important agent in enabling access to low cost energy for people in developing countries [4]. For decentralized applications, PEC cells have the benefit of simplicity. On the other hand, existing PV installations can easily be retrofitted with an electrolysis unit. Additionally, for PV/electrolysis, the PV installation on the roof requires little maintenance, whereas the electrolyzer can conveniently be placed in a location where it is easily accessible.

For any given $\mathrm{H}_{2}$ generation strategy, storage is a critical issue. In decentralized applications, conversion to hydrocarbons may be difficult. $\mathrm{H}_{2}$ has a good gravitational energy density $\left(120 \mathrm{MJ} \mathrm{kg}^{-1}\right)$, but its volumetric energy density is extremely low $\left(10.8 \mathrm{MJ} \mathrm{m}^{-3}\right)$. To increase it, $\mathrm{H}_{2}$ has been pressurized up to $700 \mathrm{~atm}$, liquefied at $20 \mathrm{~K}$, or stored in sorbent materials such as metal hydrides or metal organic frameworks [63]. These methods bring about additional financial and energetic costs, and an appropriate energy density has not yet been reached. For decentralized stationary applications, one could simply store the $\mathrm{H}_{2}$ locally in large containers at low pressure. Pressurization to $8 \mathrm{~atm}$ requires $4 \%$ of the energy content of $\mathrm{H}_{2}$, compared to $20 \%$ for 700 atm [42, 64]. A typical household requires about $10 \mathrm{kWh}$ of electrical energy per day. Accounting for FC, DC-AC converter and storage energy losses, this increases to $23 \mathrm{kWh}$, which corresponds to almost $700 \mathrm{~g}$ of $\mathrm{H}_{2}$. At $8 \mathrm{~atm}$, a volume of $1 \mathrm{~m}^{3}$ suffices for storing this amount. Although this volume is prohibitive for automotive applications, containers of 1-2 $\mathrm{m}^{3}$ are realistic for residential use, and the low associated pressures impose fewer requirements on the materials and equipment used. This simple storage solution solves one of the most difficult terms of the hydrogen equation, and can facilitate the transition to a hydrogen economy.

\section{AIR-BASED SOLAR HYDROGEN PRODUCTION}

In the previous considerations, PV/electrolysis and PEC systems working with liquid water were discussed. The use of liquid water has some important drawbacks. When using proton exchange membranes for product separation, the water should be of very high purity to avoid membrane poisoning by dissolved salts. For centralized applications, the locally very high consumption of water can be problematic, especially in arid, sun-rich regions. For any type of application, the use of liquid water entails the need for pumps, tubing, filters and frost protection measures [65]. Moreover, corrosion is more likely to occur in liquid phase. All of these implications result in higher cost, reduced efficiency and shorter lifetime.

All of these issues would be solved by using air as the source of water [66]. Operation in air avoids problems associated with gas bubble formation and light absorption by liquid water [67]. Both sunlight and water vapor can be found almost anywhere in the world, so in theory no additional input is required. Although water concentration in air is rather low, the moderate current density encountered in solar $\mathrm{H}_{2}$ devices implies they should be able to extract sufficient water from it. Some authors have suggested the use of air as a water feedstock recently $[21,68,69]$. They noted the important effect of relative humidity on performance, whereas absolute humidity has less importance. Spurgeon and Lewis showed that a vapor phase electrolyzer can reach a current density of $20 \mathrm{~mA} \mathrm{~cm}{ }^{-2}$, congruent with current densities of PV and PEC devices, but found that performance dropped steeply at reduced relative humidity [21]. Their work suggests that ion exchange membranes can be operated in vapor phase, albeit at lower current densities than usually encountered in electrolyzers.

Air-based cells are a light-weight, elegant and stand-alone solution for solar $\mathrm{H}_{2}$ generation. Although gas phase systems have been investigated, air-based devices were never seriously considered. Recently, an experimental proof-ofconcept was presented by some of the current authors [66]. Here, we propose a basic model to investigate the potential of such cells. We show that the concept is realistic and deserves further investigation. 


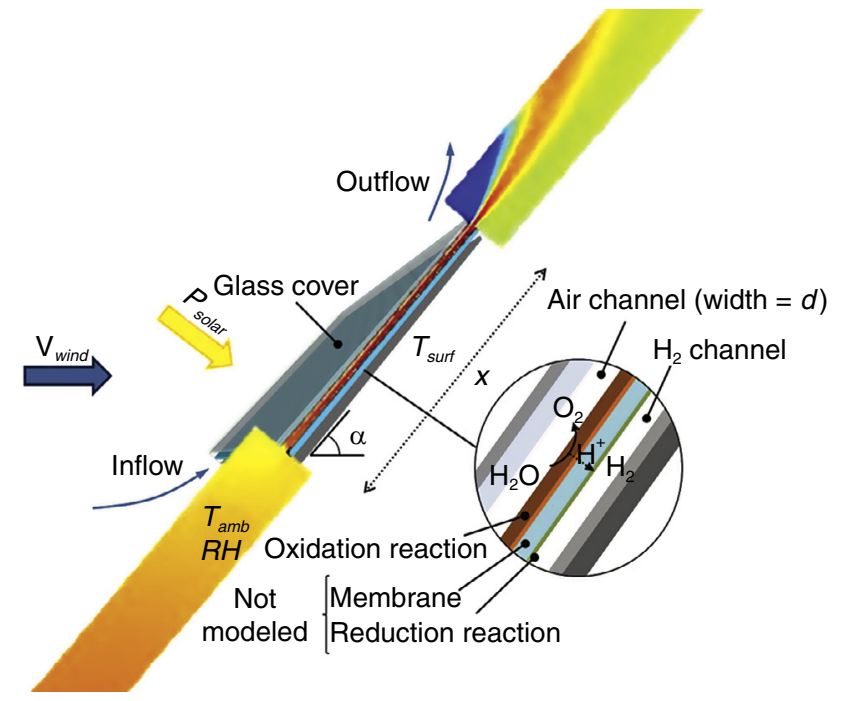

Figure 7

Drawing of the modeled air-based PEC cell. Only the yellow/ red zones are included in the model. Variables are indicated, values used in the base case are indicated in Table 1.

\subsection{Modeling of an Air-Based PEC Device}

Contrary to liquid phase devices, for gas phase devices water supply may become limiting. Herein, we model a conceptual device converting water vapor from air into hydrogen in order to verify the feasibility of such a concept. The model is based on a numerical analysis using the Comsol Multiphysics software package. The design of the device is shown in Figure 7. We assume an inclined panel with a glass cover creating a channel of $2 \mathrm{~cm}$ width. The channel is open at the bottom and the top to allow for natural circulation of air which can provide water vapor to the reaction channel. At the reaction surface, water is oxidized into oxygen and protons:

$$
\begin{gathered}
\mathrm{H}_{2} \mathrm{O} \rightarrow \frac{1}{2} \mathrm{O}_{2}+2 \mathrm{H}^{+}+2 \mathrm{e}^{-} \\
r_{\mathrm{H}_{2} \mathrm{O}}=k_{\mathrm{H}_{2} \mathrm{O}}\left(\frac{p_{\mathrm{H}_{2} \mathrm{O}}}{p_{\mathrm{H}_{2} \mathrm{O}}^{e q}}\right)^{n}
\end{gathered}
$$

$r_{\mathrm{H}_{2} \mathrm{O}}$ is defined as the rate of water consumption, $k_{\mathrm{H}_{2} \mathrm{O}}$ is a rate constant and $n$ is the reaction order. The actual rate is determined by the vapor pressure $\left(p_{\mathrm{H}_{2} \mathrm{O}}\right)$. Oxygen is released into the reaction channel and evacuated. An actual device should contain a membrane to ensure product separation, so protons and electrons would be transferred to a second compartment for pure hydrogen production, but these processes are not modeled in this analysis. Water oxidation in the gas phase has been reported to follow first order kinetics $(n=1$; Eq. 6) [69]. However, the detailed kinetics of water oxidation in the gas phase are not known. The observed first order dependence on humidity was attributed to the effects of humidity-dependent proton conductivity from oxidation to reduction sites. For the simulations performed here, we assumed a device following first order kinetics with nominal STH efficiency of $10 \%$ at $100 \%$ relative humidity. This STH efficiency can be achieved by state of the art liquid cells, and is often encountered in prospective PEC analyses [18, 27]. The detailed structure and composition of the system is not specified, as this is irrelevant for the current model. A $10 \%$ STH efficiency results in a rate constant $\left(k_{\mathrm{H}_{2} \mathrm{O}}\right)$ of $416 \mu \mathrm{mol} \mathrm{m} \mathrm{m}^{-2} \mathrm{~s}^{-1}$. STH efficiency $(\eta)$ is calculated using:

$$
\eta=r_{\mathrm{H}_{2} \mathrm{O}} \cdot 0.237 \mathrm{~J} \mu \mathrm{mol}^{-1} \cdot P_{\text {solar }}^{-1}
$$

based on input of solar energy $\left(P_{\text {solar }}\right)$ and output of hydrogen energy [45]. The model calculates velocity vector fields, temperature distributions, and vapor pressures by solving the mass conservation equation and the Navier-Stokes equation with a gravitational force (F) modeled using the Boussinesq approximation and ideal gas assumption (Eq. 8), the energy conservation equation (Eq. 9), and the diffusion-convection species transport equation with a water sink ( $R_{\text {sink }} ;$ Eq. 10$)$ :

$$
\begin{aligned}
& \rho(\mathbf{u} \cdot \nabla) \mathbf{u}= \\
& \nabla \cdot\left[-\rho \mathbf{I}+\mu\left(\nabla \mathbf{u}+(\nabla \mathbf{u})^{T}\right)-\frac{2}{3} \mu(\nabla \cdot \mathbf{u}) \mathbf{I}\right]+\mathbf{F} \\
& c_{p} \rho \mathbf{u} \nabla T=\nabla \cdot(k \nabla T) \\
& \nabla(D \nabla c)-\nabla(\mathbf{u} c)=R_{\text {sink }}
\end{aligned}
$$

The fluid is characterized by density, $\rho$, dynamic viscosity, $\mu$, specific heat capacity, $c_{p}$, thermal conductivity, $k$, and water diffusivity, $D$. The variables of interest are the temperature scalar field, $T$, the velocity vector field, $\mathbf{u}$, and the water concentration scalar field, $c$. The relative humidity is calculated using the saturation vapor pressure, which is obtained through Magnus' equation (Eq. 11):

$$
p_{\mathrm{H}_{2} \mathrm{O}}^{e q}=611.213 e^{\frac{17.5043 \cdot T}{241.2+T}}
$$

The base case input parameters for the model are listed in Table 1. Unless otherwise stated, these parameters were used for all the results shown. Intentionally, the incident light intensity was fixed for all scenarios, to allow 
TABLE 1

Parameters used in the model for the base case scenario. Unless otherwise stated, these parameters are used for all the results

\begin{tabular}{l|c}
\hline Panel length, $x$ & $0.8 \mathrm{~m}$ \\
\hline Reaction surface temperature, $T_{\text {surf }}$ & $40^{\circ} \mathrm{C}$ \\
\hline Reaction channel width, $d$ & $0.02 \mathrm{~m}$ \\
\hline $\begin{array}{l}\text { Nominal STH efficiency at } 100 \% \text { relative } \\
\text { humidity, } \eta_{\text {nom }}\end{array}$ & $10 \%$ \\
\hline Reaction order, $n$ & 1 \\
\hline Incident light intensity, $P_{\text {solar }}$ & $1000 \mathrm{~W} \mathrm{~m}^{-2}$ \\
\hline Inclination angle, $\alpha$ & $50^{\circ}$ \\
\hline Temperature (ambient), $T_{\text {amb }}$ & $20^{\circ} \mathrm{C}$ \\
\hline Pressure (ambient), $p_{\text {amb }}$ & $1 \mathrm{~atm}$ \\
\hline Relative humidity, $R H$ & $60 \%$ \\
\hline Diffusion coefficient air-water vapour, $D$ & $2.5 \cdot 10^{-5} \mathrm{~m}^{2} \mathrm{~s}^{-1}$ \\
\hline Wind speed, $v_{\text {wind }}$ & $0 \mathrm{~m} \mathrm{~s}^{-1}$ \\
\hline
\end{tabular}

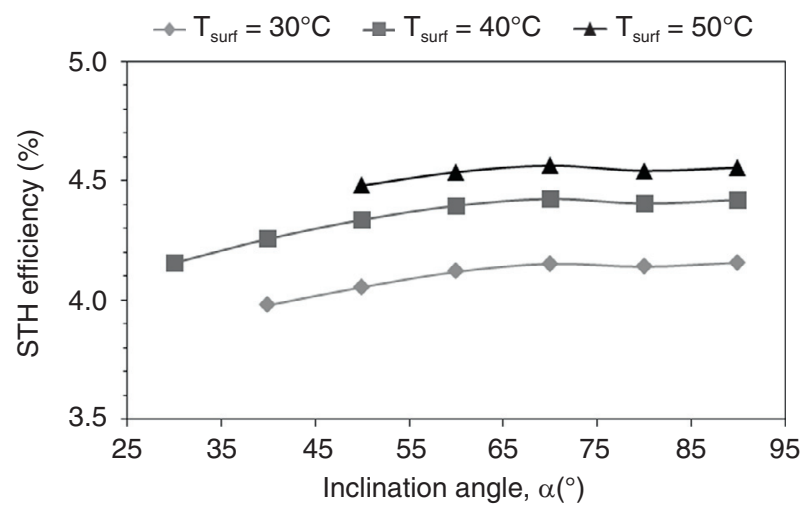

Figure 8

STH efficiency as a function of reaction surface temperature $\left(T_{\text {surf }}\right)$ and inclination angle $(\alpha)$. All other parameters are given in Table 1.

the examination of inclination angle without interference of this parameter. The reaction surface was assumed to be at a slightly elevated temperature $\left(40^{\circ} \mathrm{C}\right.$ for the base case), accounting for partial radiation absorption at a solar irradiation of $1000 \mathrm{~W} \mathrm{~m} \mathrm{~m}^{-2}$. Under these conditions, the flow regime was laminar (Grashof number $<1.5 \cdot 0^{-9}$ ).

The STH efficiency of the modeled device is shown in Figure 8. At increased surface temperature and increased inclination angle, the air flow through the channel increases and STH efficiency is higher. The asymptotic increase in the

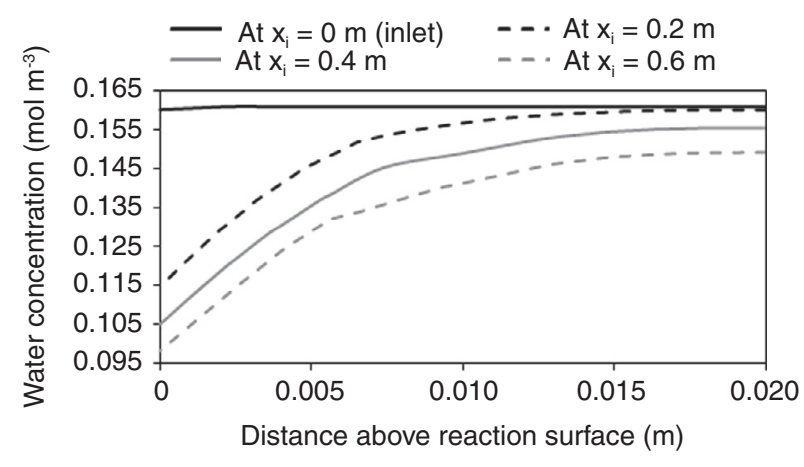

Figure 9

Water concentration profiles perpendicular to the reaction surface, at different points along the reaction surface length.

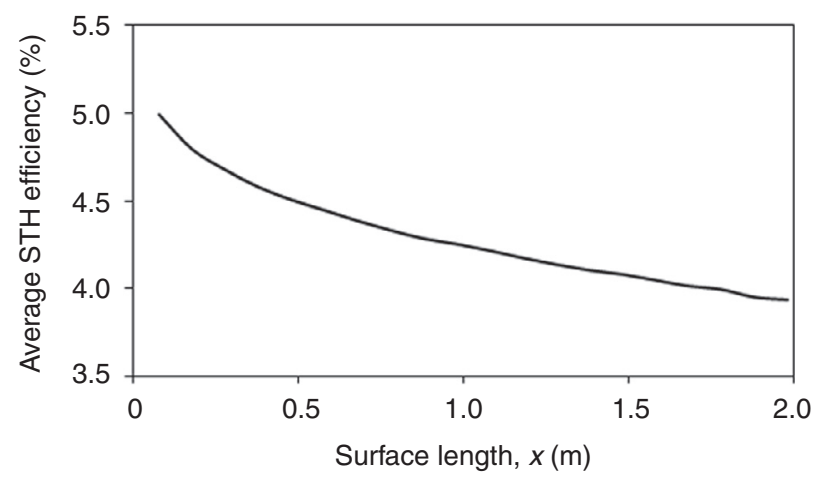

Figure 10

STH efficiency as a function of panel length $(x)$.

efficiency with inclination, i.e. air flow rate, is observed to result from mass transport limitations rather than reactant limitations. The water vapor concentration distribution along the channel width and length is depicted in Figure 9, showing the change of the initially homogeneously distributed water vapor towards a non-homogeneous distribution caused by the developed thermal and velocity boundary layers. The resulting decrease in the water vapor concentration at the reaction surface leads to a lower STH efficiency along the channel length, as depicted in Figure 9. Consequently, the STH efficiency also decreases for panels with longer channel lengths, as depicted in Figure 10. The boundary layer thickness decreases with channel air flow rate. When the boundary layer thickness becomes almost negligible, the relative humidity at the surface approaches the ambient relative humidity and the water supply is no longer limiting.

At $40^{\circ} \mathrm{C}$ and an inclination angle of $50^{\circ}$, the air velocity through the channel is $0.23 \mathrm{~m} \mathrm{~s}^{-1}$, which corresponds to an air supply of $5.8 \cdot 10^{-3} \mathrm{~m}^{3} \mathrm{~s}^{-1} \mathrm{~m}^{-2}$. Thus water is supplied at a rate of $59 \mathrm{mg} \mathrm{s}^{-1} \mathrm{~m}^{-2}$, whereas only 


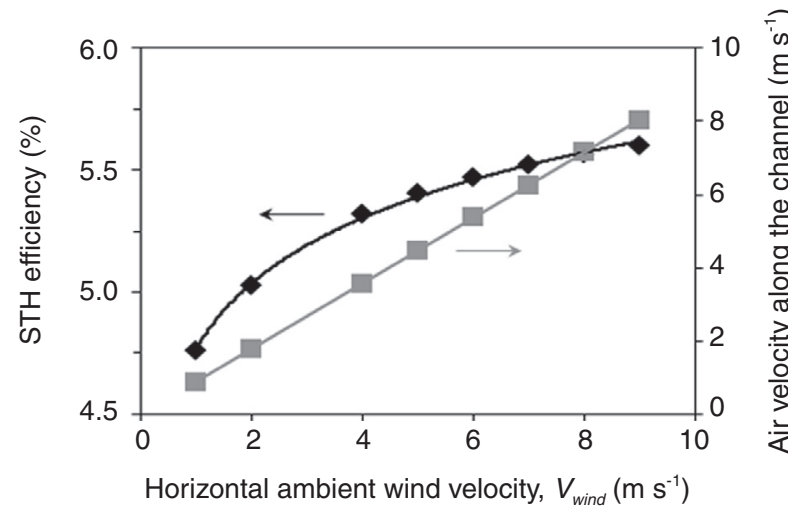

Figure 11

STH efficiency and channel air velocity when the model accounts for wind. Horizontal wind velocities are indicated. Other parameters are given in Table 1.

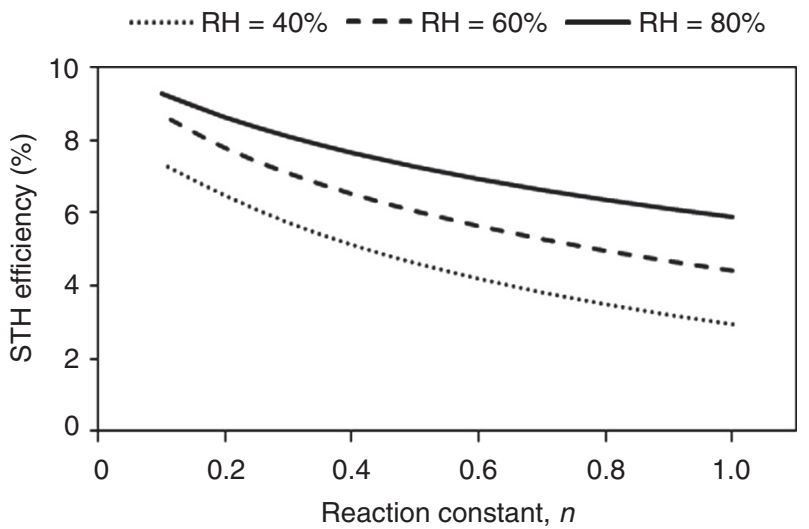

Figure 12

STH efficiency as a function of reaction constant $(n)$. Three scenarios are calculated with different relative humidity.
$0.75 \mathrm{mg} \mathrm{s}^{-1} \mathrm{~m}^{-2}$ is consumed (assuming $\eta=10 \%$ ). It is clear that ample water is supplied to the reaction channel for the reaction to proceed at a realistic rate. Still, STH efficiency is only $4.3 \%$ and slightly increasing with higher air flow rates, due to boundary layer effects. Besides natural convection, wind may contribute to the air flow over the reaction surface (Fig. 11). A typical wind velocity of $4-5 \mathrm{~m} \mathrm{~s}^{-1}$ increases the air flow rate in the reaction channel to about $4 \mathrm{~m} \mathrm{~s}^{-1}$, and the STH efficiency increases to $5.3 \%$. As the air flow rates further increase, boundary layer thickness decreases and the STH efficiency approaches a maximum of $\sim 6 \%$, which is the limit dictated by the ambient relative humidity of $60 \%$. The Richardson number was $<0.1$ inside the reaction channel, which shows that natural convection by buoyancy in the channel is negligible in presence of wind. Reynolds number was $1000-4$ 000, indicating laminar or transitional flow.

We propose two strategies to improve the performance of air-based devices. First, the increase in momentum exchange by introducing turbulent flow, reducing the boundary layer thickness and increasing the surface water concentration. A drawback of turbulent flow would be additional pressure losses, which reduce the air flow rate in the channel. Second, materials development for low humidity operation by enhanced water management. For example, FC have been modified with silica fillers and heteropolyacids for better performance at low humidity [70]. The response of different materials to changing relative humidity is reflected in the effective reaction order. The first order dependence on vapor pressure (Eq. 2) was previously suggested to be caused by changes in proton conductivity [69]. If water management at the catalyst surface and inside the membrane of a device could be optimized, the effective reaction order will be lower.
Figure 12 shows that, despite very low surface water concentrations, high STH efficiencies could be achieved with appropriate materials engineering. If a reaction order of 0.1 is achieved, STH efficiency increases from $4.3 \%$ to $8.7 \%$ for the base case.

At this stage, we conclude that the challenge for air-based devices is not to provide water to the reaction channel, but to get it to the surface. This could be addressed both by reactor engineering (inducing turbulence) and materials engineering (enhancing performance at low humidity). Further expansion and validation of the model is required to assess the potential of these strategies.

\section{CONCLUSIONS AND OUTLOOK}

Even though solar $\mathrm{H}_{2}$ generation is still under intensive development, some of the existing technologies can and are already being commercialized. Besides continued research, commercial development should already begin today, as reaching market penetration may be an even bigger challenge than the technical challenges solved in the past. This article reviewed the most important practical considerations for PV/electrolysis and PEC systems. Both deserve attention, as it is not yet clear which approach will be the most successful in the future. While PEC cells hold the promise of lower cost, lower environmental impact and less complexity, at the moment reality is arguing against this technology, which is still facing many technical difficulties. Will PEC cells become the next nuclear fusion? Or will they soon overcome their limitations and become the next big renewable technology? We should hope for the latter, and in the meantime make use of the possibilities 
PV/electrolysis give us. PV/electrolysis systems are currently the most mature technology and more likely to be cost-effective on short term.

As PEC devices mature, more detailed technoeconomic and life cycle assessments are desired. Only then will we be able to determine whether they are a useful technology. In the end, probably both systems will be used depending on the application. The world's future energy demand of 30 TW by 2050 will have to be met by a balanced mix of wind, solar and other sustainable technologies, deployed at large to small scales, and backed up by reliable storage media.

A very simple PEC cell design is possible if water vapor from air is used rather than a purified liquid water source. In this case, the PEC cell requires no input but sunlight and air. We provided a first assessment of such a concept by numerical modeling. We showed that supply of water vapor by natural convection and wind is not a problem. However, optimal performance at reduced relative humidity will require appropriate reactor and materials engineering.

\section{ACKNOWLEDGMENTS}

JR acknowledges the Research Foundation - Flanders (FWO) for a PhD grant. JAM is supported by the Flemish government (Methusalem long-term structural funding).

\section{REFERENCES}

1 Van de Krol R., Grätzel M. (2012) Photoelectrochemical hydrogen production, Springer.

2 Hooke R., Martín-Duque J., Pedraza J. (2012) Land transformation by humans: a review, GSA Today 4-10.

3 Bruninx K., Madzharov D., Delarue E., D’haeseleer W. (2013) Impact of the German nuclear phase-out on Europe's electricity generation-A comprehensive study, Energy Policy 60, 251-261.

4 Cook T.R., Dogutan D.K., Reece S.Y., Surendranath Y., Teets T.S., Nocera D.G. (2010) Solar energy supply and storage for the legacy and nonlegacy worlds, Chem. Rev. 110, 6474-6502.

5 Armaroli N., Balzani V. (2011) Towards an electricity-powered world, Energy Environ. Sci. 4, 3193-3222.

6 Barnhart C.J., Dale M., Brandt A.R., Benson S.M. (2013) The energetic implications of curtailing versus storing solar- and wind-generated electricity, Energy Environ. Sci. 6, 2804-2810.

7 Fuel Cells (2000) at http://fuelcells.org.

8 Hydrogen Filling Stations Worldwide, at http://www.netinform. net/h2/H2Stations.

9 Hydrogen Fueling Stations, at http://www.afdc.energy.gov/ fuels/hydrogen_stations.html.

10 Honda. Home Energy Station, at http://world.honda.com/ FuelCell/HomeEnergyStation/.
11 Nanoptek, at http://nanoptek.com/.

12 Waterstofnet, at http://waterstofnet.eu/.

13 High VLO City, at http://highvlocity.eu/.

14 HyFLEET:CUTE, at http://www.global-hydrogen-busplatform.com/.

15 CHIC project, at http://chic-project.eu/.

16 Van Noorden R. (2012) Artificial Leaf Faces Economic Hurdle, Nat. News. at http://www.nature.com/news/artificial-leaf-faceseconomic-hurdle-1.10703.

17 Carbajales-Dale M., Barnhart C.J., Benson S.M. (2014) Can we afford storage? A dynamic net energy analysis of renewable electricity generation supported by energy storage, Energy Environ. Sci. 7, 1538-1544.

18 Pinaud B.A., Benck J.D., Seitz L.C., Forman A.J., Chen Z., Deutsch T.G., James B.D., Baum K.N., Baum G.N., Ardo S., Wang H., Miller E., Jaramillo T.F. (2013) Technical and economic feasibility of centralized facilities for solar hydrogen production via photocatalysis and photoelectrochemistry, Energy Environ. Sci. 6, 1983-2002.

19 Conibeer G., Richards B. (2007) A comparison of PV/ electrolyser and photoelectrolytic technologies for use in solar to hydrogen energy storage systems, Int. J. Hydrogen Energy 32, 2703-2711.

20 Rau S., Vierrath S., Ohlmann J., Fallisch A., Lackner D., Dimroth F., Smolinka T. (2014) Highly Efficient Solar Hydrogen Generation-An Integrated Concept Joining III-V Solar Cells with PEM Electrolysis Cells, Energy Technol. 2, 43-53.

21 Spurgeon J.M., Lewis N.S. (2011) Proton exchange membrane electrolysis sustained by water vapor, Energy Environ. Sci. 4, 2993-2998.

22 Haussener S., Hu S., Xiang C., Weber A.Z., Lewis N.S. (2013) Simulations of the irradiation and temperature dependence of the efficiency of tandem photoelectrochemical water-splitting systems, Energy Environ. Sci. 6, 3605.

23 Peharz G., Dimroth F., Wittstadt U. (2007) Solar hydrogen production by water splitting with a conversion efficiency of $18 \%$, Int. J. Hydrogen Energy 32, 3248-3252.

24 Khaselev O., Bansal A., Turner J.A. (2001) High-efficiency integrated multijunction photovoltaic - electrolysis systems for hydrogen production, Int. J. Hydrogen Energy 26, 127-132.

25 Jacobsson J., Fjällström V., Sahlberg M. (2013) A monolithic device for solar water splitting based on series interconnected thin film absorbers reaching over $10 \%$ solar-to-hydrogen efficiency, Energy Environ. Sci. 6, 3676-3683.

26 Jacobsson J., Fjällström V., Edoff M., Edvinsson T. (2014) Sustainable Solar Hydrogen Production: From PhotoElectrochemical Cells to PV-Electrolysis and Back Again, Energy Environ. Sci. 7, 2056-2070.

27 Rongé J., Bosserez T., Martel D., Nervi C., Boarino L., Taulelle F., Decher G., Bordiga S., Martens J.A. (2014) Monolithic cells for solar fuels, Chem. Soc. Rev. 43, 7963-7981.

28 Walter M.G., Warren E.L., McKone J.R., Boettcher S.W., Mi Q., Santori E.A., Lewis N.S. (2010) Solar water splitting cells, Chem. Rev. 110, 6446-6473.

29 Berger A., Segalman R., Newman J. (2014) Material Requirements for Membrane Separators in a Water-Splitting Photoelectrochemical Cell, Energy Environ. Sci. 7, 1468-1476. 
30 National Renewable Energy Laboratory. National Center for Photovoltaics, at http://www.nrel.gov/ncpv/.

31 Seitz L.C., Chen Z., Forman A.J., Pinaud B.A., Benck J.D., Jaramillo T.F. (2014) Modeling Practical Performance Limits of Photoelectrochemical Water Splitting Based on the Current State of Materials Research, ChemSusChem 7, 1372-1385.

32 Rocheleau R.E., Miller E.L. (1997) Engineering production of hydrogen: loss analysis, Int. J. Hydrog. Energy 22, 771-782.

33 Hu S., Xiang C., Haussener S., Berger A.D., Lewis N.S. (2013) An analysis of the optimal band gaps of light absorbers in integrated tandem photoelectrochemical water-splitting systems, Energy Environ. Sci. 6, 2984-2993.

34 Newman J., Hoertz P.G., Bonino C.A., Trainham J.A. (2012) Review: An Economic Perspective on Liquid Solar Fuels, J. Electrochem. Soc. 159, A1722-A1729.

35 European Commission (2008) Hyways. The European Hydrogen Roadmap.

36 US Department of Energy (2012) Fuel Cell technologies multiyear research, development and demonstration plan, at http:// energy.gov/eere/fuelcells/fuel-cell-technologies-office-multiyear-research-development-and-demonstration-plan.

37 Parkinson B., Turner J. (2013) in Photoelectrochem. Water Split, Lewerenz H.-J., Peter L. (eds.), Royal Society of Chemistry, pp.1-18.

38 Skea J. (2014) The renaissance of energy innovation, Energy Environ. Sci. 7, 21-24.

39 Turner J.A. (2004) Sustainable hydrogen production, Science 305, 972-974.

40 McKone J.R., Gray H.B., Lewis N.S. (2013) Will Solar-Driven Water-Splitting Devices See the Light of Day? Chem. Mater. 26, 407-414.

41 Plass K.E., Filler M.A., Spurgeon J.M., Kayes B.M., Maldonado S., Brunschwig B.S., Atwater H.A., Lewis N.S., (2009) Flexible Polymer-Embedded Si Wire Arrays, $A d v$. Mater. 21, 325-328.

42 Mason J., Zweibel K. (2008) Sol. Hydrog. Gener, Rajeshwar K., McConnell R., Licht S. (eds), Springer, pp. 273-313.

43 Modestino M.A., Walczak K.A., Berger A., Evans C.M., Haussener S., Koval C., Newman J.S., Ager J.W., Segalman R.A. (2014) Robust production of purified $\mathrm{H}_{2}$ in a stable, self-regulating, and continuously operating solar fuel generator, Energy Environ. Sci. 7, 297-301.

44 Wang T., Luo Z., Li C., Gong J. (2014) Controllable fabrication of nanostructured materials for photoelectrochemical water splitting via atomic layer deposition, Chem. Soc. Rev. 43, 7469-7484.

45 Chen Z., Jaramillo T.F., Deutsch T.G., Kleiman-Shwarsctein A., Forman A.J., Gaillard N., Garland R., Takanabe K., Heske C., Sunkara M., McFarland E.W., Domen K., Miller E.L., Turner J.A., Dinh H.N. (2011) Accelerating materials development for photoelectrochemical hydrogen production: Standards for methods, definitions, and reporting protocols, J. Mater. Res. 25, 3-16.

46 Haussener S., Xiang C., Spurgeon J.M., Ardo S., Lewis N.S., Weber A.Z. (2012) Modeling, Simulation, and Design Criteria for Photoelectrochemical Water-Splitting Systems, Energy Environ. Sci. 5, 9922-9935.

47 Carver C., Ulissi Z., Ong C.K., Dennison S., Kelsall G.H., Hellgardt K. (2012) Modelling and development of photoelectrochemical reactor for $\mathrm{H}_{2}$ production, Int. J. Hydrogen Energy 37, 2911-2923.
48 European Commission (2010) Critical Raw Materials for the $E U$.

49 Du P., Eisenberg R. (2012) Catalysts made of earth-abundant elements $(\mathrm{Co}, \mathrm{Ni}, \mathrm{Fe})$ for water splitting: Recent progress and future challenges, Energy Environ. Sci. 5, 6012-6021.

50 Zhai P., Haussener S., Ager J., Sathre R., Walczak K., Greenblatt J., McKone T. (2013) Net primary energy balance of a solar-driven photoelectrochemical water-splitting device, Energy Environ. Sci. 6, 2380-2389.

51 Habas S.E., Platt H.A.S., van Hest M.F.A.M., Ginley D.S. (2010) Low-cost inorganic solar cells: from ink to printed device, Chem. Rev. 110, 6571-6594.

52 Desertec Industrial Initiative. at http://www.dii-eumena.com.

53 Haeseldonckx D., Dhaeseleer W. (2007) The use of the naturalgas pipeline infrastructure for hydrogen transport in a changing market structure, Int. J. Hydrogen Energy 32, 1381-1386.

54 Roads2HyCOM. European Hydrogen Infrastructure Atlas. Part III. Industrial distribution infrastructure, at http://www. roads 2 hy.com/r2h_Downloads.

55 Centi G., Quadrelli E., Perathoner S. (2013) Catalysis for $\mathrm{CO}_{2}$ conversion: A key technology for rapid introduction of renewable energy in the value chain of chemical industries, Energy Environ. Sci. 6, 1711-1731.

56 European Commission (2013) On the Future of Carbon Capture and Storage in Europe, $\operatorname{COM}(2013) \mathbf{1 8 0 .}$

57 Hydrogenics, Power-to-gas, http://www.hydrogenics.com/ products-solutions/energy-storage-fueling-solutions/powerto-gas.

58 Sunfire, http://www.sunfire.de.

59 ETOGAS, at http://www.etogas.com.

60 Lilliestam J., Ellenbeck S. (2011) Energy security and renewable electricity trade-Will Desertec make Europe vulnerable to the "energy weapon"? Energy Policy 39, 3380-3391.

61 Alanne K., Saari A. (2006) Distributed energy generation and sustainable development, Renew. Sustain. Energy Rev. 10, 539-558.

62 Keirstead J. (2007) Behavioural responses to photovoltaic systems in the UK domestic sector, Energy Policy 35, 4128-4141.

63 Jena P. (2011) Materials for Hydrogen Storage: Past, Present, and Future, J. Phys. Chem. Lett. 2, 206-211./refs

64 Edwards P.P., Kuznetsov V.L., David W.I.F. (2007) Hydrogen energy, Phil. Trans. A 365, 1043-1056.

65 Sathre R., Scown C.D., Morrow W.R., Stevens J.C., Sharp I.D., Ager J.W., Walczak K., Houle F.A., Greenblatt J.B. (2014) Life-cycle net energy assessment of large-scale hydrogen production via photoelectrochemical water splitting, Energy Environ. Sci. 7, 3264-3278.

66 Rongé J., Deng S., Pulinthanathu Sree S., Bosserez T., Verbruggen S.W., Kumar Singh N., Dendooven J., Roeffaers M.B.J., Taulelle F., De Volder M., Detavernier C., Martens J.A. (2014) Air-Based Photoelectrochemical Cell Capturing Water Molecules from Ambient Air for Hydrogen Production, RSC Adv. 4, 29286-29290.

67 Döscher H., Geisz J.F.J., Deutsch T.G., Turner J.A. (2014) Sunlight absorption in water-efficiency and design implications for photoelectrochemical devices, Energy Environ. Sci. 7, 2951. 
68 Xiang C., Chen Y., Lewis N.S. (2013) Modeling an integrated photoelectrolysis system sustained by water vapor, Energy Environ. Sci. 6, 3713-3721.

69 Dionigi F., Vesborg P.C.K., Pedersen T., Hansen O., Dahl S., Xiong A., Maeda K., Domen K., Chorkendorff I. (2011) Gas phase photocatalytic water splitting with $\mathrm{Rh}_{2-y} \mathrm{Cr}_{y} \mathrm{O}_{3} / \mathrm{GaN}$ : $\mathrm{ZnO}$ in $\mu$-reactors, Energy Environ. Sci. 4, $2937-2942$.

70 Bose S., Kuila T., Nguyen T.X.H., Kim N.H., Lau K.-T., Lee J.H. (2011) Polymer membranes for high temperature proton exchange membrane fuel cell: Recent advances and challenges, Prog. Polym. Sci. 36, 813-843.
Manuscript submitted in May 2014 Manuscript accepted in December 2014 Published online in April 2015

Cite this article as: J. Rongé, T. Bosserez, L. Huguenin, M. Dumortier, S. Haussener and J. A. Martens (2015). Solar Hydrogen Reaching Maturity, Oil Gas Sci. Technol 70, 5, 863-876. 